\title{
JUURNAL.RU
}

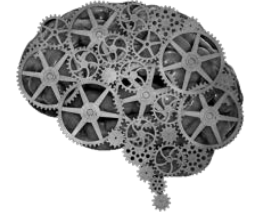

COMPANY GROUP "INTELLEKT"

\author{
Привалов Д.М., Ксандопуло С.Ю., Привалова Н.М. \\ Кубанский государственный технологический университет; \\ ООО «НПО Вертекс» \\ Краснодар, Россия
}

doi: 10.18411/lj2016-5-1-13

\section{Совершенствование приемов ресурсосбережения при утилизации попутного нефтяного газа}

Попутный нефтяной газ (ПНГ), выделяемый из нефти при ее сепарации на объектах добычи и подготовки, является одним из важнейших ресурсов углеводородного сырья. Значительный рост мирового потребления нефти и природного газа, наблюдаемый в последние десятилетия, наряду с истощением их запасов, требует максимально эффективного использования всех видов углеводородных ресурсов. В этой связи попутный нефтяной газ рассматривается как ценный источник энергии и сырьё химической и энергетической промышленности.

Но, несмотря на высокую теплотворную способность, дальнейшее использование ПНГ затруднительно, в связи с нестабильностью состава и наличием высокого числа примесей, что приводит к существенным затратам на очистку (подготовку) газа.

Утилизация попутного нефтяного газа должна быть направлена на высокотехнологичное освоение месторождений нефти, на ликвидацию неблагоприятных последствий сжигания газа на «факелах» и возврата в оборот углеводородного сырья.

Применение современных технологий позволяет использовать конечный продукт утилизации попутного газа в качестве топлива для получения 
электроэнергии на газотурбинных электростанциях и тепла. Обеспечивая подготовку и утилизачию попутного газа нефтедобывающая компания не только избегает штрафов за загрязнение окружающей среды, но и обеспечивает свою компанию качественной электроэнергией и теплом. В настоящее время критическим для работы технологических цуехов установки комплексной подготовки газа (УКПГ) является значение капельного уноса жидкости с газовым потоком, выходящим из сепаратора. Его значение достигает 4,5 г/м3 и более.

Для исключения капельного уноса жидкости с газовым потоком, выходящим из сепаратора, произведена модернизация блока сепарирования установки комплексной подготовки газа, которая обеспечила качественное отделение капельной жидкости из газового потока при эффективной производительности технологического процесса по сырому газу не ниже 6 млн м3 газа/сут.

Целью проекта было обеспечение массовой концентрации жидкости в очищенном газе не более 0,004 г/м3, на максимально и минимально возможных режимах эксплуатации аппаратов.

В результате проведенного технологического расчета в качестве фильтра сепаратора ступени низкого давления принят вертикальный аппарат диаметром 3,2 м, в котором установлены две ступени сепарации:

- 1 ступень - сепарационный пакет СГВ-7-3,2/16;

- 2 ступень - фильтрующие элементы ЭФВП-Г-(1-8)-(175-102-1025)КО-21 в количестве 90 шт;

- $\quad$ производительность по газу - 86575...222302 ${ }^{+15} \mathrm{M}^{3} /$ ч (при $\mathrm{P}=0,1013$ МПа и $\left.\mathrm{t}=0^{\circ} \mathrm{C}\right)$;

- $\quad$ производительность по жидкости - 0...5000кг/ч;

- $\quad$ давление рабочее (изб.) - 1,55 МПа;

- давление расчетное (изб.) - 1,61МПа; 
- $\quad$ температура рабочая $-10 \ldots 40,{ }^{\circ} \mathrm{C}$;

- $\quad$ общее гидравлическое сопротивление аппарата - 0,0096 МПа;

- $\quad$ концентрация жидкости в очищенном газе - не более 50 ppm при максимальном размере капель 10 мкм;

- $\quad$ степень очистки газа от твердых частиц размером более 10 мкм $100 \%$;

Принцип действия СГВ-7 (рис.1) основан на извлечении механических и жидких примесей из потока газа под действием центробежных сил.

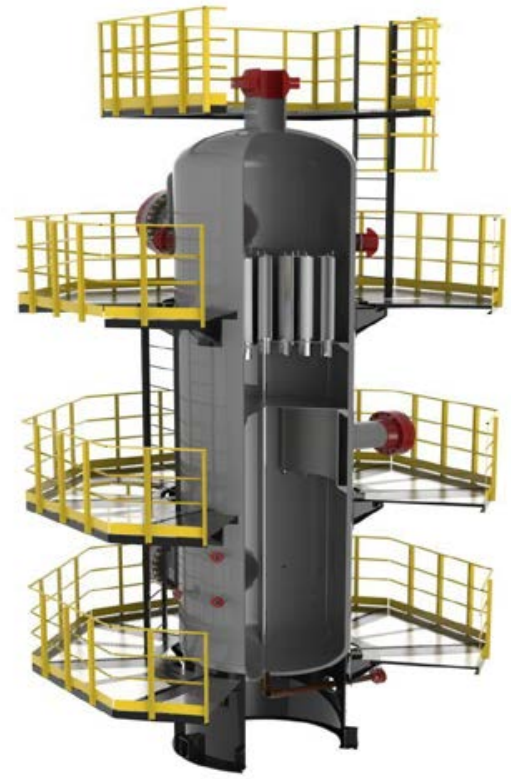

Рис.1 Фильтр-сепаратор ступени низкого давления

Фильтр-сепаратор входной ступени низкого давления представляет собой вертикальный аппарат диаметром 3200 мм, установленный на цилиндрической опоре, и состоит из следующих секций:

- $\quad$ - входной сепарационный узел;

- - - выходной сепарационной тарелки с фильтрующими элементами.

Аппарат входит в состав оборудования площадки газоперекачивающих агрегатов низкого давления и среднего давления установки комплексной подготовки газа Новопортовского нефтегазоконденсатного месторождения и подлежит эксплуатации в условиях холодного макроклиматического района со средней температурой наиболее холодной пятидневки не ниже минус $43^{\circ} \mathrm{C}, \mathrm{c}$ 
абсолютной минимальной температурой окружающего воздуха не ниже минус $51^{\circ} \mathrm{C}$. Унос из аппарата 4-6 мг/ м3.

\section{Литература}

1. Исмаилов В.С., Юрьев Э.В., Кулиев А.С. Опыт использования высокоэффективного оборудования для очистки газа на основе газовых сепараторов СГВ-7. Актуальные технико-технологические разработки и решения в области подготовки, транспорта газа и утилизации ПНГ: сборник статей:/ ООО «НПО Вертекс».- Краснодар: Издательский Дом Юг, 2014. - 52 с. 